Article

\title{
The Influence of a Migration Background on Attitudes Towards Immigration
}

\author{
Charlotte Clara Becker ${ }^{1,2}$ \\ ${ }^{1}$ Institute of Sociology and Social Psychology, University of Cologne, 50923 Cologne, Germany; \\ E-Mail: becker@wiso.uni-koeln.de \\ ${ }^{2}$ Cologne Graduate School in Management, Economics and Social Sciences, University of Cologne, 50923 Cologne, \\ Germany
}

Submitted: 28 June 2019 | Accepted: 20 November 2019 | Published: 27 December 2019

\begin{abstract}
Migration is an ever-increasing phenomenon that is unfailingly the topic of public discourse. Recently, empirical interest has expanded to include the study of attitudes towards immigration. However, the focus usually lies on the opinion of natives, that is, persons without a migration background. This is unfortunate, because in many countries the proportion of people with a migration background is quite high, and many of them hold the citizenship of the receiving country. I expect individuals with a migration background to have more favourable attitudes towards immigration than the general population because they can identify more strongly with other immigrants due to their own migration history. Furthermore, I expect this difference to decrease with each subsequent migrant generation, with earlier generations holding more positive attitudes than later generations. For the analyses, I pooled data from the 2008-2016 rounds of the American General Social Survey. The subsample used included 7,362 respondents, 2,811 of whom had a migration background. Moreover, the data set allowed the differentiation of three generations of migrants. The results support the theoretical expectations. Persons with a migration background had more favourable attitudes towards immigration compared to those without a migration background. However, a closer look revealed that this is the case only for first-generation immigrants. The attitudes of second- and third-generation immigrants differed from each other on the $5 \%$ level, but the attitudes of neither group differed from that of the general population when the migrants' regional origins were controlled for.
\end{abstract}

\section{Keywords}

attitudes towards immigration; immigration; migrant generation; American General Social Survey

\section{Issue}

This article is part of the issue "Immigration from the Migrants' Perspective" edited by Alice Ramos (Institute of Social Sciences, Portugal), Eldad Davidov (University of Cologne, Germany/University of Zurich, Switzerland), Peter Schmidt (University of Giessen, Germany), Marta Vilar Rosales (Institute of Social Sciences, Portugal) and Dina Maskileyson (University of Cologne, Germany).

(C) 2019 by the author; licensee Cogitatio (Lisbon, Portugal). This article is licensed under a Creative Commons Attribution 4.0 International License (CC BY).

\section{Introduction}

Due to the conflicts and economic struggles in the Middle East, Africa and Latin America and the subsequent migration waves to Europe and the US, the topic of immigration has become increasingly important in recent years. Besides discussing the actual migration, the issue of immigration attitudes and opinions in the receiving countries is often covered by the media. Here, the focus usually lies on showcasing the opinions of natives.
Reports on the immigration attitudes of persons with a migration background can rarely be found, even though in many countries (like the US) the share of people with a migration background in the population is quite high. For instance, $24 \%$ of the US population were either born outside the US or have at least one parent who was (Trevelyan et al., 2016). Furthermore, those with a migration background are not just an important part of the society, they comprise a significant group of voters who can have an impact on election outcomes and legislation. 
In countries in which citizenship is granted to all those born within the country (i.e., second and later generations), such as the US, this is especially relevant because the share of voters with a migration background is likely to be comparatively high.

In the following I will examine whether and to what extent attitudes towards immigration are different between natives and individuals with a migration background in the US context. By using data from the American General Social Survey (GSS; Smith, Davern, Freese, \& Hout, 2018) it will be possible to test whether the opinion on immigration differs between persons with and without a migration background, and if it is relevant whether people have a first-, second- or third-generation migration background. Before the analyses can be executed, some theoretical background on the existing literature and theories will be given and concrete expectations on the results will be framed.

\section{Literature}

Most research on immigration attitudes focuses on the majority population, that is, natives who do not have a migration background. Besides that, there is a less known line of research in the US exploring minorities and immigrants' attitudes towards this issue. Research combining these two positions, and therefore allowing a comparison of the attitudes of those with and without a migration background, is however scarce. This is especially true for research on differences among migrant generations. Therefore, in order to give an overview, studies analysing the attitudes of minorities and migrants towards immigration as well as research on the majority population, which somewhat includes migrants' attitudes towards immigration, are evaluated in the following. Additionally, first insight on generational differences will be discussed, before highlighting the scientific contributions of this article.

Research has so far shown that immigrants' attitudes towards other minorities varied with the groups that were considered, with more positive attitudes being displayed towards each other by those sharing the same religion and having more contact (Hindriks, Verkuyten, \& Coenders, 2014). Since this study's sample only included respondents with a migration background, it is unclear to what extent the respondents differed in their opinion from the native majority of the population. An earlier study by Berry and Kalin (1995), in contrast, was able to reveal such differences in Canada between those belonging to a majority and those belonging to a minority. They showed that minority members, in comparison to the French-Canadian majority, felt more comfortable in interacting with other ethnicities. Further, those belonging to a minority had significantly more favourable attitudes towards a diverse and multicultural nation and were more tolerant towards other ethnicities. However, no question on the attitude towards immigration per se was asked in the survey.
Additionally, there have been studies specifically exploring minorities' attitudes towards immigration. This is especially true for the US. Whereas Hood, Morris, and Shirkey (1997) focused on self-identified Hispanics, Diamond (1998) was more interested in the attitudes of African Americans. The latter identified an overall trend across 14 different studies using African-American heritage as a control variable: In comparison to white US citizens, African Americans were less likely to be against immigration. Due to their sample being restricted to Hispanics, Hood et al. (1997) were not able to make similar comparisons. However, being able to make such comparisons with the attitudes of the majority of the population is an important aspect in trying to understand and explain the attitudes of subgroups towards immigration. Only when this comparison is possible, can conclusions be drawn about the differences and similarities of the groups concerning their attitudes towards immigration.

Likewise, when looking at immigrants' rather than minorities' attitudes towards immigration, this problem persists. Many researchers were exclusively interested in the attitudes of people with migration backgrounds and hence chose data sets which did not include respondents without migration backgrounds or with migration backgrounds removed by several generations, as it is the case for most US citizens. Studies focusing on immigrants' attitudes while allowing the comparison with the majority are scarce. One approach in this direction was done by Binder, Polinard, and Wrinkle (1997) who compared Mexican-American and Anglo-American attitudes towards various immigration policies. They found that Anglo Americans showed significantly stronger support for more restrictive immigration policies. In a descriptive comparison of the attitudes towards allowing more legal immigrants into the US, few differences were found between the two groups. A more recent comparison between the majority population, described as persons born to two US-born parents, and persons born to at least one foreign-born parent, came to similar conclusions (Buckler, Swatt, \& Salinas, 2009). Those who belonged to the majority of the population were more likely to support stricter immigration policies and border protection efforts. Again, however, there was no multivariate analyses comparing the immigration attitudes. In Europe, even less research has been conducted on this issue. As part of their research on immigrants' attitudes towards immigration, Just and Anderson (2015) made a brief comparison between foreign- and native-born respondents in 18 European countries. They found that foreign-born respondents showed significantly more positive attitudes towards immigration compared to nativeborn respondents.

Another way to approach the topic is to look at existing studies trying to explain attitudes towards immigration in general rather than immigrants' attitudes and their difference to the general population specifically. Many researchers investigating the influence of per- 
sonal characteristics and traits on immigration attitudes included inter alia variables on the respondents' heritage or migration background (Bridges \& Mateut, 2014; Hainmueller \& Hiscox, 2007; Mayda, 2006; O’Rourke $\&$ Sinnott, 2006). Since most of these researchers did not discuss the effects of these variables directly, information must be gleaned by a close inspection of their models and tables. For instance, in their assessment of attitudes towards immigration of migrants of a different and of the same race, Bridges and Mateut (2014) showed that those classified as foreign were significantly less likely to be opposed to immigration. Similarly, Hainmueller and Hiscox's (2007) as well as O'Rourke and Sinnott's (2006) results indicated that those who were born in the country of data collection were significantly less likely to take a pro-immigration stance compared to those born elsewhere. The same was true for those whose parents were born in the interview country as reflected in the significantly higher probability of these persons to endorse a substantial reduction in the number of immigrants in comparison to those with parents born abroad (O'Rourke \& Sinnott, 2006). Also, having parents with a foreign citizenship significantly increased respondents' likelihood to be pro-immigration (Mayda, 2006).

Overall, it appears that in studies focusing on the comparison of immigrants' and non-immigrants' attitudes towards immigration as well as in studies focusing on the majority population, those with some form of migration background had significantly more positive attitudes towards immigration policies and immigration than those without a migration background (Bridges \& Mateut, 2014; Buckler et al., 2009; Hainmueller \& Hiscox, 2007; Just \& Anderson, 2015; Mayda, 2006; O’Rourke \& Sinnott, 2006).

While similar conclusions can be drawn from the presented studies, it should be noted that each of them operationalized the concept "migration background" differently. While some researchers controlled for migration backgrounds by simply excluding all participants who were born outside the country of interest (Mayda, 2006), others opted to include variables assessing the birth place of the respondents or their ancestors (e.g., Bridges \& Mateut, 2014; Buckler et al., 2009; Hainmueller \& Hiscox, 2007; Mayda, 2006; O’Rourke \& Sinnott, 2006). The simplest form was to include the respondent's birthplace (Hainmueller \& Hiscox, 2007). This made it possible to compare first-generation migrants with the rest of the population. An alternative was the inclusion of the birthplace of the respondent's parents (Buckler et al., 2009; Mayda, 2006) as well as a single variable covering both birthplace aspects simultaneously (Bridges \& Mateut, 2014). Neither of them allowed a comparison between different generations of migrants. A comparison of multiple generations of migrants with each other as well as with persons without a migration background requires separate variables for the different generations' birth places to be included into the analyses.
Only one of the above-mentioned studies allowed such comparisons: O'Rourke and Sinnott's (2006) results suggest that those who are native born to native-born parents were most likely to report anti-immigrant attitudes, followed by those who could be described as second-generation migrants. Respondents with a firstgeneration migration background reported the most positive attitude towards immigration. In addition to O'Rourke and Sinnott's (2006) study, other studies utilising migrant-exclusive data sets can be employed to further explore the differences between the generations. Among Latino immigrants, for example, Rouse, Wilkinson, and Garand (2010) found that those belonging to the second generation as well as those belonging to later generations were significantly less likely to report a pro-immigration attitude and had less favourable attitudes towards allowing more legal immigrants into the US, compared to first-generation Latino immigrants. On the other hand, in his descriptive analyses of Latino attitudes, Suro (2005) showed that whereas first-generation Latinos were more likely to think that immigrants strengthen the country, there were only few differences in the generations' opinions about whether the amount of legal immigration from Latin America should be reduced or increased. Similarly, when comparing first- and second-generation Mexican Americans with Mexican Americans whose families have been in the country for more generations, Polinard, Wrinkle, and de la Garza (1984) found no significant differences in their attitudes towards the rate of immigration as well as other aspects of immigration. The sample for this study, however, was not nationally representative, rather it was comprised of Mexican Americans from Texas, with a large share of the respondents living along the Mexican border. The high concentration of immigrants in this area might have increased respondents perceived competition for resources (Hood et al., 1997). As suggested in a large body of literature on intergroup conflict, this perceived threat can be used as an explanation for negative attitudes towards outgroup members (Blalock, 1967; Campbell, 1967; Riek, Mania, \& Gaertner, 2006), such as new or potential immigrants (Meuleman, Davidov, \& Billiet, 2009; Quillian, 1995). Hence, the conclusion drawn from studies conducted in specific regions of the US might not be transferable to generational differences within the population of the entire country. In summary, the currently existing literature does not draw a clear picture as to whether later generations of migrants have less favourable attitudes towards immigration in comparison to those whose families immigrated more recently. Studies with broader, nationally representative samples, including respondents with various migration backgrounds and from different origins would be necessary to focus on these questions in detail.

Notwithstanding these findings, it is apparent that there is very limited research on the comparison of $\mathrm{mi}$ grants' and non-migrants' attitudes towards immigration. First insights concerning this effect had to be gath- 
ered from studies that either did not focus on attitudes towards immigration or did only include migration aspects as control variables into their analyses. The goal of this study is to bring the comparison of migrants' and non-migrants' attitudes towards immigration into focus. In addition, this article will continue the line of work on the attitudes of the different migrant generations. Here, an approach similar to that utilised by O'Rourke and Sinnott (2006) will be followed. In contrast to their work and similar studies on immigrant specific data sets, however, the following study actively differentiates three generations of migrants from the rest of the population. By examining and comparing the attitudes of the different generations, a closer look at the assimilation of attitudes towards immigrants and the differences among generations as well as between them and the general population will be possible.

\section{Theory}

Reviewing the literature, I find two theories providing an underlying rationale as to why attitudes towards immigration may differ between a country's native citizens and their counterparts with a migration background: the concept of social distance and the contact theory.

First, social distance is seen as a subjective measure describing the "degrees of understanding and intimacy" (Park, 1924, p. 339) between persons as well as between social groups. It is often measured as the willingness to engage with persons from specific social groups at various levels of intimacy (Bogardus, 1925, 1967; Hindriks et al., 2014). The higher the willingness to engage, the lower the social distance. Within social groups the willingness to engage is usually high; hence, the perceived social distance is low. However, as social distance towards a group increases, the uncertainty that comes with the engagement increases as well due to the decrease in knowledge that individuals have about the other person and his or her group (Hill, 1984; Maddux, Scheiber, \& Bass, 1982). This uncertainty leads to more difficult interactions as well as to the reinforcement and amplification of existing prejudices (Hill, 1984; Maddux et al., 1982). Hence, people generally have a more positive attitude towards those individuals whom they perceive less social distance towards, in other words, persons who are similar to themselves, and they prefer interacting and engaging with them rather than with more socially distant others (Hill, 1984).

It is likely that persons with a migration background show a greater understanding for new immigrants and immigration in general, because they experienced the same themselves or have ancestors who experienced immigration. Therefore, these individuals are expected to perceive a smaller social distance between themselves and new or potential immigrants. The social distance between those without a migration background and new immigrants on the other hand is expected to be larger. Hence, those with a migration background are expected to have a more positive attitude towards immigration than those without a migration background (Hypothesis 1).

But not all migrant generations are expected to perceive the same social distance to new or potential immigrants. Those who migrated themselves most likely feel that they belong to the same social group (Constantinou \& Harvey, 1985; Masuda, Hasegawa, \& Matsumoto, 1973; Masuda, Matsumoto, \& Meredith, 1970) and possibly perceive the lowest social distance. This group of individuals can relate best to the potential immigrants because they experienced the same situation themselves. In comparison, second- or thirdgeneration migrants did not have the experience themselves and therefore possibly perceive a larger social distance. Especially third-generation migrants, who do not even hear tales of migration recounted by their parents, is expected to show less understanding towards new migrants. Therefore, of the three generations examined here, they are expected to perceive the largest social distance towards immigrants. In conclusion, individuals with a first-generation migration background are expected to have more positive attitudes towards immigrants than individuals with a second- or thirdgeneration background (Hypothesis 2). Moreover, individuals with a second-generation migration background are expected to have more positive attitudes towards immigration than third-generation migrants (Hypothesis 3 ). In other words, the attitudes towards immigration become less positive with the increasing time span since the own family's migration experience.

Second, the contact theory should also be taken into consideration when trying to explain differences in immigration attitudes of those with and without a migration background. It assumes that interaction between two people or two social groups is necessary in order to dissolve group barriers existing between them (Allport, 1954). Through contact, people start seeing each other as individuals with unique characteristics rather than as simple representatives of a uniform group (Brewer \& Miller, 1984). This individualisation also leads to a decrease in discrimination and stereotypes as well as to more positive attitudes towards each other and each other's groups (Brewer \& Miller, 1984). However, contact alone is not sufficient to develop a positive attitude towards a group (Amir, 1969). Rather, certain characteristics of the contact situation influence the potential positive change (Brewer \& Miller, 1984). The main situation characteristics assumed to increase the positive attitude are a similar social status of the persons involved, a collective goal or cooperative interdependence, the possibility to refute existing stereotypes, direct personal contact, as well as the presence of egalitarian norms (Allport, 1954; Brewer \& Miller, 1984; Cook, 1978).

Existing research supports the assumptions made by the contact theory (Pettigrew \& Tropp, 2006) and has shown that people who live in mixed neighbourhoods as well as people who have immigrants in their 
social network have more positive attitudes towards immigration (Hayes \& Dowds, 2006; Jolly \& DiGiusto, 2014; Quillian, 1995). Since many families with migration backgrounds live in ethnically diverse neighbourhoods (Musterd, 2005; Semyonov \& Glikman, 2009), and generally migrants tend to have other migrants in their direct social network (Lubbers, Molina, \& McCarty, 2007), it can be expected that people with a migration background have more regular contact with new immigrants. Individuals without a migration background, on the other hand, tend to live in neighbourhoods predominantly inhabited by natives (Musterd, 2005; Semyonov \& Glikman, 2009) and to have fewer inter-ethnic friendships and contacts with immigrants (Lancee \& Hartung, 2012; Martinović, 2013). This is especially relevant because contact with immigrants in the neighbourhood and within one's direct social network probably meets the requirements for a positive attitude change. For that reason, the contact theory supports the earlier presented notion that those with a migration background are likely to have a more positive attitude towards immigration than those without (Hypothesis 1).

One can also assume that not all generations of migrants will have the same amount of contact with new immigrants. While first-generation migrants might have difficulties getting in contact with non-migrants because of language barriers, second-generation migrants, even though raised in the neighbourhoods their parents live in, should have relatively more contact to natives because they have lived their entire lives in the host country and have grown up learning the native language. Existing research supports this assumption, showing that second-generation migrants tend to have more native friends than first-generation migrants (Martinović, 2013) and are more likely to live in less segregated neighbourhoods (Denton \& Massey, 1988; Freeman, 2000). Because of their relatively increased contact with natives, they probably have less contact with new immigrants. This could be especially true for third-generation migrants. Therefore, the contact theory supports the idea that later generations of migrants will have less positive attitudes towards immigration than earlier generations (Hypothesis 2 and Hypothesis 3). Hence, the contact theory endorses the expectations held for the results by the social distance concept, not only when it comes to the effect of a migration background in general, but also with respect to the effects of the different generations. Table 1 summarizes the hypotheses.

\section{Data and Variables}

The analyses presented in this article utilise pooled data from the 2008 to 2016 biennial rounds of the GSS, collected mostly via personal interviews by the independent research organisation NORC at the University of Chicago (Smith et al., 2018). The data set, a nationally representative sample of 11,446 respondents, was chosen as it contains information on the respondents' attitude towards immigration and all information necessary to identify three different generations of migrants. However, since $35 \%$ of respondents did not answer the attitude question, the following analyses will all use the subsample of 7,362 respondents between the ages of 18 and 88 who provided an answer to this question. While the respondents participating in the 2010 round were slightly more likely to answer the question, there are no systematic differences in the socio-demographic characteristics between those who answered the question and those who did not.

To measure the attitude towards immigration (dependent variable), a well-established question used by several other researchers in the past (e.g., Mayda, 2006; O'Rourke \& Sinnott, 2006) was applied: Do you think the number of immigrants to America nowadays should be: (1) increased a lot, (2) increased a little, (3) remain the same, (4) reduced a little, or (5) reduced a lot. A higher response on this question indicated a less positive attitude towards immigration. Additionally, robustness checks with different groupings of the five categories were run, all yielding very similar results to the ones presented below.

The general migration background was defined as a binary variable, which had the value 1 if the respondent had a migration background and the value 0 otherwise. Only respondents classified as first-, second- or third-generation migrants according to the definitions below were coded as having a migration background. Migrants of later generations could not be identified in the data set and were therefore coded as members of the reference category "without a migration background." Additionally, I created a binary variable for each of the three migrant generation. It scored the value 1 if the respondent belonged to the specific generation and the value 0 otherwise.

A first-generation migrant was defined by being born outside of the US and having both parents also born abroad. This definition is in line with classifications used

Table 1. Summary of the hypotheses.

\begin{tabular}{ll}
\hline Hypothesis 1 & $\begin{array}{l}\text { Individuals with a migration background have more positive attitudes towards immigration compared } \\
\text { to those without a migration background. }\end{array}$ \\
\hline Hypothesis 2 & $\begin{array}{l}\text { Individuals with a first-generation migration background have more positive attitudes towards } \\
\text { immigration than individuals with a second- or third-generation migration background. }\end{array}$ \\
\hline Hypothesis 3 & $\begin{array}{l}\text { Individuals with a second-generation migration background have more positive attitudes towards } \\
\text { immigration than third-generation migrants. }\end{array}$ \\
\hline
\end{tabular}


by many other researchers (e.g., Algan, Dustmann, Glitz, \& Manning, 2010). The demarcation of the second generation, however, is not so unambiguous. While researchers agree that being born in the host country is a necessary requirement (Algan et al., 2010; Bauer \& Riphahn, 2007; Jensen \& Chitose, 1994), there is a disagreement as to whether both parents (Algan et al., 2010; Dustmann, Frattini, \& Lanzara, 2012) or only one parent (Alba, Logan, Lutz, \& Stults, 2002; Bauer \& Riphahn, 2007; Jensen \& Chitose, 1994) has to be born abroad in order to be classified as a second-generation migrant. The latter, slightly more common approach is the one applied here. Only those who were born within the US and have at least one parent who was born outside the US were categorised as second-generation migrants. As there has only been limited research on thirdgeneration migrants, a common definition remains to be determined. But researchers agree that in order to be a third-generation migrant, both parents as well as the respondent him- or herself need to be born in the host country (so in this case within the US), and the grandparents need to be born abroad (e.g., Alba et al., 2002; Hammarstedt, 2009). The number of grandparents born outside the host country necessary is again debatable. Alba et al. (2002) as well as Hammarstedt (2009) declared one foreign-born grandparent to be sufficient for this classification. This definition is also used here, as it guarantees that, by the definition presented above, at least one parent is a second-generation migrant.

Besides the migration background, another migration-related aspect was operationalised: the origin. It is possible that migrants with different roots have different opinions on immigration. Here North American, European, African, Asian, and Spanish-speaking South and Middle American roots were distinguished and integrated as binary variables (details reported in Table A1 in the Appendix). Respondents with a migration background which could not be attributed to any of these groups formed the "Other Origin" category. Respondents without a migration background, as described above, were coded 0 on all origin variables even though they might have foreign roots when looking more than three generations back. Because some of the origin categories are underrepresented there will be analyses with and without them.

In addition to the variables linked to the migration background, further variables, such as personal characteristics and socio-economic background, were included. One factor which has repeatedly been associated with attitudes towards immigration is age, with older people showing more negative attitudes (Bridges \& Mateut, 2014; Hainmueller \& Hiscox, 2007; O’Rourke \& Sinnott, 2006). Therefore, age in years was included into the analyses as well as gender, whose effects are disputed (Mayda, 2006; O'Rourke \& Sinnott, 2006). Here, the binary variable male, equalling 1 for males and 0 for females, was used. Also, a binary variable describing the respondents' race was included, since previous research indicated that race might influence the attitude towards immigration (Diamond, 1998). This effect was captured by the variable non-white, which equalled 1 for respondents identifying as a race other than white and 0 for respondents identifying as white. Another important aspect to include was the respondents' education, since a positive effect of education on pro-immigrant attitudes has been found by various researchers (e.g., Bridges \& Mateut, 2014; Hainmueller \& Hiscox, 2007; Hindriks et al., 2014). Education was measured by the highest year of school completed. This included completed years of college and university. Also related to the concept of income and work, labour force status was considered. Even though unemployment did not have a significant effect in other studies (O'Rourke \& Sinnott, 2006), binary variables measuring the participation in the labour force were included. Respondents who were temporarily not working or unemployed were defined as unemployed (1) while all others were assigned the value 0. Similarly, binary variables for inactive (in education, retired, and homemakers) respondents and for respondents coded as "other labour force status" in the GSS were included. The reference category persisted of those who reported a part- or full-time employment status. Class could not be included into the analyses due to the fact that those inactive in the labour market largely displayed missings on the class variables. However, additional analyses on a subsample of the employed and unemployed respondents showed similar results to those presented below when including class in the form of ISCO-08 coding. Detailed information on these analyses can be obtained from the author upon request.

Lastly, four binary variables indicating the year of data collection $(2010,2012,2014$, and 2016) were added to the analyses. In each case, the respondents who participated in the respective year received a score of 1 , while all other respondents were assigned the value 0 . The reference category will be all respondents who participated in 2008. Including these variables will ensure that time trends as well as potential political changes are accounted for.

Detailed information on all variables, their operationalisation as well as some descriptive statistics can be found in Table A2 in the Appendix.

\section{Results}

The average respondent was 47.94 years old and completed 13.60 years of education. With $55 \%$, the slight majority was female. Three-quarters of the respondents identified as white. Besides that, most respondents ( $n=4,358$ ) were working part- or full-time. A migration background was reported by $38 \%$ of respondents of which the majority was classified as third-generation migrants. Almost half of those with a migration background named a European country as their place of origin (48\%).

Analyses revealed that $24 \%$ of respondents indicated support of the notion that immigration to the US should 
be reduced "a lot," 23\% thought it should be reduced "a little" and the category endorsed most often (38\%) was the "remain the same" category. Only $10 \%$ of respondents thought that immigration should be increased "a little" and even fewer (5\%) that it should be increased "a lot."

Figure 1 indicates that there are substantial differences in the attitudes towards immigration between respondents with and without a migration background as well as between the different migrant generations. Out of the respondents without a migration background $27 \%$ shared the notion that immigration should be "reduced a lot." This response was given by approximately the same number of third-generation migrants (25\%), but only $6 \%$ of first-generation migrants. Generally, it appears that with each successive generation, the attitude towards immigration became increasingly less positive (i.e., more negative), with the attitude of the third generation approaching that of respondents with no migration background.

In order to test whether and to what extent these differences are significant and hold after controlling for aspects of the migration history as well as socioeconomic factors, I applied ordered logit regressions across four models. Detailed information regarding each models' sample composition in relation to the respondents' migration background can be found in Table A3 in the Appendix.

Model 1 describes the influence of the general migration background on the attitudes towards immigration under the consideration of all socio-demographic variables and year dummies described above. The migration background had a significant negative effect, indicating that those with a migration background were less likely to think that immigration into the US should be reduced "a lot" and were more likely to support the notion that immigration should be increased "a lot." Whereas gender and labour force status had no significant effects, the likelihood for negative attitudes towards immigration in- creased with age and decreased with education and the identification as non-white. Additionally, a time trend towards more positive attitudes was found.

In Model 2, I substituted the general migration background for the specific origins of the migrants, this allowed for the different ethnic groups of migrants to be compared to those without a migration background. The results indicate that migrants, regardless of origin, were less likely to support the view that immigration should be reduced "a lot." This being said, there were significant differences among the views of those with a migration background: Those of North American and African origin showed the most positive attitude towards immigration while those of European origin show the least positive. Concerning the socio-demographic variables as well as the years of data collection, the results appear to be similar to those found for Model 1.

Overall, these results support Hypothesis 1, indicating that individuals with a migration background have more positive attitudes towards immigration compared to their counterparts without a migration background. When comparing the two models, both the Akaike Information Criterion (AIC) and Bayesian Information Criterion (BIC) support the model differentiating between the migrants' ethnic groups (Model 2) over the model without the origin aspects (Model 1 ).

The next step was to analyse and compare the effects of the different migration generations on the attitude towards immigration. Here, I estimated a model similar to Model 1, exchanging the general migration background for the three generation variables (Model 3). Additionally, I ran a model in which both the three generations as well as the various origins were considered (Model 4).

In Model 3, all three migrant generations exerted a significant effect on the attitude towards immigration, showing that all three generations had more favourable attitudes towards immigration than those without a migration background. However, t-tests comparing the co-

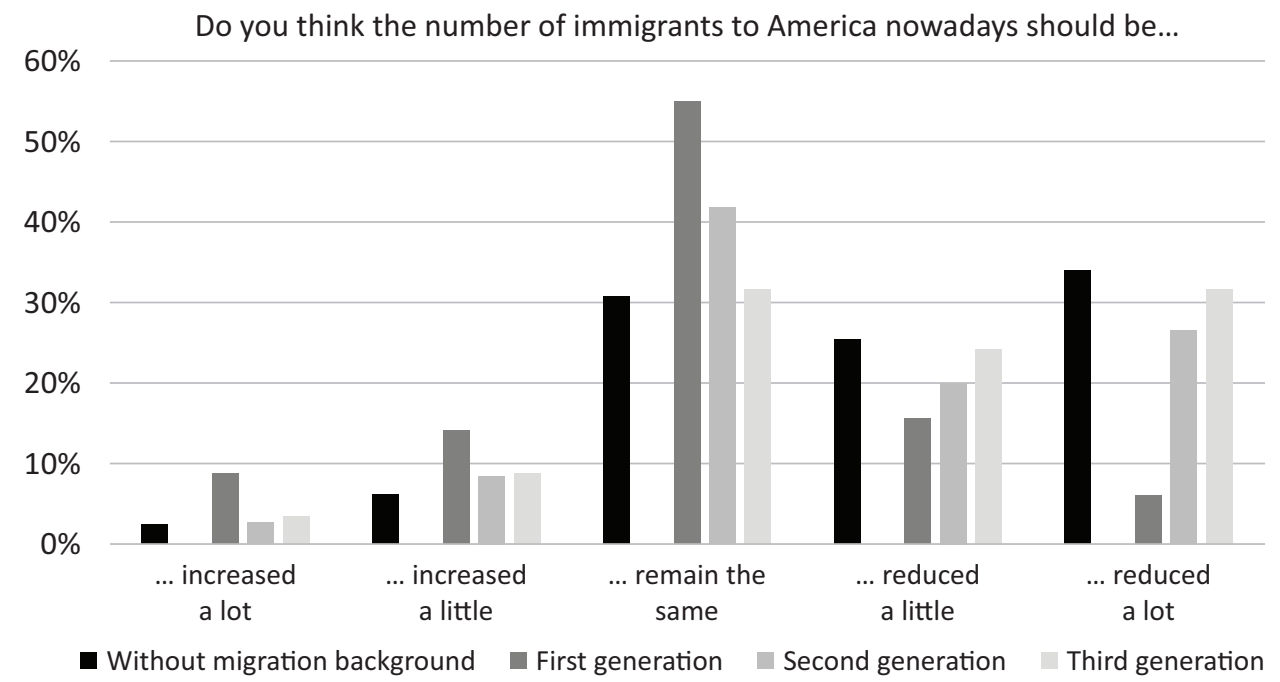

Figure 1. Attitudes towards immigration by migrant generation in percentage points. 
Table 2. Ordered logit models with general migration background and separate migration generations.

\begin{tabular}{|c|c|c|c|c|}
\hline & Model 1 & Model 2 & Model 3 & Model 4 \\
\hline Migration Background & $\begin{array}{l}-0.58^{* * *} \\
(-12.84)\end{array}$ & & & \\
\hline First-generation & & & $\begin{array}{l}-1.28 * * * \\
(-17.55)\end{array}$ & $\begin{array}{l}-0.72 * \\
(-2.34)\end{array}$ \\
\hline Second-generation & & & $\begin{array}{l}-0.50 * * * \\
(-6.39)\end{array}$ & $\begin{array}{c}-0.01 \\
(-0.03)\end{array}$ \\
\hline Third-generation & & & $\begin{array}{l}-0.20 * * * \\
(-3.39)\end{array}$ & $\begin{array}{c}0.21 \\
(0.73)\end{array}$ \\
\hline North American & & $\begin{array}{l}-1.25^{* * *} \\
(-13.81)\end{array}$ & & $\begin{array}{l}-0.95^{* *} \\
(-3.07)\end{array}$ \\
\hline European & & $\begin{array}{l}-0.27^{* * *} \\
(-4.55)\end{array}$ & & $\begin{array}{l}-0.32 \\
(-1.08)\end{array}$ \\
\hline African & & $\begin{array}{l}-1.32^{* * *} \\
(-5.87)\end{array}$ & & $\begin{array}{l}-0.86^{*} \\
(-2.30)\end{array}$ \\
\hline Asian & & $\begin{array}{l}-0.88^{* * *} \\
(-6.78)\end{array}$ & & $\begin{array}{l}-0.42 \\
(-1.29)\end{array}$ \\
\hline $\begin{array}{l}\text { Spanish-speaking South } \\
\text { and Middle American }\end{array}$ & & $\begin{array}{l}-0.97^{* * *} \\
(-7.51)\end{array}$ & & $\begin{array}{l}-0.52 \\
(-1.60)\end{array}$ \\
\hline Other Origin & & $\begin{array}{l}-0.55^{* *} \\
(-3.18)\end{array}$ & & $\begin{array}{l}-0.25 \\
(-0.74)\end{array}$ \\
\hline Age & $\begin{array}{l}0.01 * * * \\
(8.32)\end{array}$ & $\begin{array}{l}0.01 * * * \\
(6.31)\end{array}$ & $\begin{array}{l}0.01^{* * *} \\
(7.51)\end{array}$ & $\begin{array}{l}0.01^{* * *} \\
(6.70)\end{array}$ \\
\hline Male & $\begin{array}{l}-0.06 \\
(-1.42)\end{array}$ & $\begin{array}{l}-0.06 \\
(-1.38)\end{array}$ & $\begin{array}{l}-0.07 \\
(-1.51)\end{array}$ & $\begin{array}{l}-0.07 \\
(-1.48)\end{array}$ \\
\hline Non-White & $\begin{array}{l}-0.59 * * * \\
(-11.29)\end{array}$ & $\begin{array}{l}-0.42 * * * \\
(-7.24)\end{array}$ & $\begin{array}{l}-0.42 * * * \\
(-7.76)\end{array}$ & $\begin{array}{l}-0.40^{* * *} \\
(-6.78)\end{array}$ \\
\hline Education & $\begin{array}{l}-0.08^{* * *} \\
(-10.27)\end{array}$ & $\begin{array}{l}-0.09 * * * \\
(-11.38)\end{array}$ & $\begin{array}{l}-0.09 * * * \\
(-11.77)\end{array}$ & $\begin{array}{l}-0.10^{* * *} \\
(-12.11)\end{array}$ \\
\hline Unemployed & $\begin{array}{c}0.06 \\
(0.68)\end{array}$ & $\begin{array}{c}-0.01 \\
(-0.08)\end{array}$ & $\begin{array}{c}0.02 \\
(0.18)\end{array}$ & $\begin{array}{l}-0.02 \\
(-0.26)\end{array}$ \\
\hline Inactive & $\begin{array}{l}-0.09 \\
(-1.64)\end{array}$ & $\begin{array}{l}-0.09 \\
(-1.66)\end{array}$ & $\begin{array}{l}-0.10 \\
(-1.90)\end{array}$ & $\begin{array}{l}-0.10 \\
(-1.89)\end{array}$ \\
\hline Other Labour Force Status & $\begin{array}{c}0.20 \\
(1.42)\end{array}$ & $\begin{array}{c}0.10 \\
(0.74)\end{array}$ & $\begin{array}{c}0.13 \\
(0.96)\end{array}$ & $\begin{array}{c}0.05 \\
(0.38)\end{array}$ \\
\hline 2010 & $\begin{array}{l}-0.21^{* *} \\
(-2.89)\end{array}$ & $\begin{array}{l}-0.21^{* *} \\
(-2.82)\end{array}$ & $\begin{array}{l}-0.23 * * \\
(-3.12)\end{array}$ & $\begin{array}{l}-0.22 * * \\
(-3.00)\end{array}$ \\
\hline 2012 & $\begin{array}{l}-0.28^{* * *} \\
(-3.77)\end{array}$ & $\begin{array}{l}-0.27^{* * *} \\
(-3.60)\end{array}$ & $\begin{array}{l}-0.29 * * * \\
(-3.89)\end{array}$ & $\begin{array}{l}-0.28^{* * * *} \\
(-3.62)\end{array}$ \\
\hline 2014 & $\begin{array}{l}-0.35^{* * *} \\
(-4.97)\end{array}$ & $\begin{array}{l}-0.32^{* * *} \\
(-4.40)\end{array}$ & $\begin{array}{l}-0.35^{* * *} \\
(-5.00)\end{array}$ & $\begin{array}{l}-0.33^{* * * *} \\
(-4.53)\end{array}$ \\
\hline 2016 & $\begin{array}{l}-0.51^{* * *} \\
(-7.51)\end{array}$ & $\begin{array}{l}-0.48^{* * *} \\
(-6.93)\end{array}$ & $\begin{array}{l}-0.52^{* * *} \\
(-7.55)\end{array}$ & $\begin{array}{l}-0.49 * * * \\
(-7.02)\end{array}$ \\
\hline Number of observations & 6949 & 6662 & 6921 & 6640 \\
\hline Log likelihood & -9623.84 & -9157.54 & -9504.28 & -9083.79 \\
\hline $\begin{array}{l}\mathrm{AIC} \\
\mathrm{BIC}\end{array}$ & $\begin{array}{l}19279.68 \\
19389.22\end{array}$ & $\begin{array}{l}18357.08 \\
18499.97\end{array}$ & $\begin{array}{l}19044.56 \\
19167.72\end{array}$ & $\begin{array}{l}18215.57 \\
18378.79\end{array}$ \\
\hline $\begin{array}{l}\text { Chi value: t-test first and } \\
\text { second generation }\end{array}$ & & & $64.27^{* * *}$ & $48.86 * * *$ \\
\hline $\begin{array}{l}\text { Chi value: t-test second and } \\
\text { third generation }\end{array}$ & & & $10.85^{* * *}$ & $4.90^{*}$ \\
\hline $\begin{array}{l}\text { Chi value: t-test first and } \\
\text { third generation }\end{array}$ & & & $154.59 * * *$ & $80.57 * * *$ \\
\hline
\end{tabular}

Notes: $t$ statistics in parentheses; ${ }^{*} p<0.05,{ }^{* *} p<0.01,{ }^{* * *} p<0.001$. 
efficients revealed that the effects differed significantly in strength. The more generations ago the family came to the US, the more likely the claim that immigration to the US should be reduced "a lot" is supported. These findings support Hypotheses 2 and 3.

However, when additionally introducing the origin variables into the analyses (Model 4), the results changed. Whereas in comparison to those without a migration background, first-generation migrants still had a lower probability of expressing that immigration into the United States should be reduced "a lot," the effect for the second and third generation appeared to be no longer significant, indicating that second- and third-generation migrants do not differ from the general population in their attitudes towards immigration.

The coefficient comparison for Model 4 again revealed that the effect for the first generation was significantly more negative than the effects for the second and third generation. Further, and only at the $5 \%$ level, it appeared that the coefficient for the second generation was more negative than the one for the third generation. The latter being the only migration aspect throughout the analyses indicating that those with a migration background could have more negative attitudes than the general population. While the difference between the two coefficients appeared to be significant, it has to be kept in mind that neither of the two generations differed significantly from those without a migration background.

Interestingly, the results also revealed that those with a North American or African migration background were significantly less likely to support the strong reduction of immigration. All other origins did not have a significant effect on the attitude when simultaneously controlling for the migrant generation. Concerning all other control variables, similar effects to those in Model 1 and Model 2 were found in both models analysing migrant generations.

Both the AIC and the BIC endorse the usage of the full Model 4 over the restricted Model 3. The results support both Hypothesis 2, postulating that firstgeneration migrants have more positive attitudes towards immigrants than second- and third-generation migrants, and Hypothesis 3, which expected respondents with a second-generation migration background to have more positive attitudes towards immigration than those with a third-generation background. However, even though Hypothesis 3 did find empirical support, it is important to point out that neither second- nor thirdgeneration migrants differed from the general population in their attitudes when control variables for the migrants' origins were included in the analyses.

\section{Conclusion}

The literature review and the theories suggested that migrants' attitudes towards immigration can be expected to be more positive than the attitudes toward immigration of the general population. Further, they led to the expectation that later generations of migrants will have less positive attitudes towards immigration than earlier generations. The analyses revealed strong support for Hypothesis 1 , showing that respondents with a migration background, no matter their origin, were more likely to favour increasing the number of migrants into the US. Similarly, Hypothesis 2 found corroboration. Individuals belonging to the first generation showed more positive attitudes towards immigration in comparison to secondand third-generation migrants. The results further revealed that the attitudes of second-generation migrants were more positive than the attitudes of the third generation. It should be noted, however, that under the consideration of migrants' origins, neither of the two generations differed significantly from those without a migration background. This might be because second- and third-generation migrants are well integrated into the society and, hence, have adopted the natives' attitudes and values.

One aspect that was not considered in the present study but could still be of great relevance is whether and to what extent respondents have contact to persons with migration backgrounds. As the contact theory describes, interaction with members of a certain group should, under the right situational conditions, positively influence the attitude towards this group (Brewer \& Miller, 1984). Therefore, the inclusion of a variable measuring the contact to migrants could show whether the attitude differences between individuals with and without a migration background and the different generations could partly or maybe even fully be attributed to the contact. Due to considerable limitations of the present data, however, such an approach was not possible here.

Besides the contact to migrants, the definition of the migration background and specifically of the different generations might influence the results as well. Here, the most common operationalisations were used, but other definitions could be justified as well. Especially for the third generation, little research exists, and multiple different definitions are conceivable. Future studies could examine in what way the different definitions influence the results, as it is possible that more restrictive definitions, for example, requiring more than one parent or grandparent to be born abroad, lead to stronger effects. Such an enquiry was beyond the scope of this article.

Not only would it be interesting to test different operationalisations of the migrant generations, the choice of the dependent variable should also be discussed. The analyses presented here measured attitudes towards immigration by asking respondents for their views on the number of immigrants that should be allowed to enter the country. This question is highly related to immigration policy. Attitudes towards immigration, however, are multi-faceted, covering much more than policy aspects alone. Hence, other questions and measurements, such as whether immigrants make countries more liveable (European Social Survey, 2018) or whether the respondents feel their culture or society is threatened by immi- 
gration (de Graaf, Kalmijn, Kraaykamp, \& Monden, 2010; ISSP Research Group, 2015), could be used as well.

In conclusion, there are still many unresolved difficulties in researching immigrants' attitudes towards immigration which require further attention. Yet despite the many aspects future research needs to consider, the migration background seems to be a relevant characteristic when explaining immigration attitudes: Having a migration background influences the formation of positive attitudes towards other immigrants. Therefore, migrants' opinions on immigration should not be disregarded but rather taken into account, particularly in countries with a high share of people with migration backgrounds.

\section{Conflict of Interests}

The author declares no conflict of interests.

\section{References}

Alba, R. D., Logan, J., Lutz, A., \& Stults, B. (2002). Only English by the third generation? Loss and preservation of the mother tongue among the grandchildren of contemporary immigrants. Demography, 39(3), 467-484. https://doi.org/10.1353/dem.2002.0023

Algan, Y., Dustmann, C., Glitz, A., \& Manning, A. (2010). The economic situation of first and secondgeneration immigrants in France, Germany and the United Kingdom. The Economic Journal, 120(542), F4-F30. https://doi.org/10.1111/j.1468-0297.2009. 02338.x

Allport, G. W. (1954). The nature of prejudice. Reading, MA: Addison-Wesley Publishing Company.

Amir, Y. (1969). Contact hypothesis in ethnic relations. Psychological Bulletin, 71(5), 319-342. https://doi. org/10.1037/h0027352

Bauer, P., \& Riphahn, R. T. (2007). Heterogeneity in the intergenerational transmission of educational attainment: Evidence from Switzerland on natives and second-generation immigrants. Journal of Population Economics, 20(1), 121-148. https://doi.org/10.1007/ s00148-005-0056-5

Berry, J. W., \& Kalin, R. (1995). Multicultural and ethnic attitudes in Canada: An overview of the $1991 \mathrm{Na}-$ tional Survey. Canadian Journal of Behavioural Science/Revue Canadienne Des Sciences Du Comportement, 27(3), 301-320. https://doi.org/10.1037/ 0008-400X.27.3.301

Binder, N. E., Polinard, J. L., \& Wrinkle, R. D. (1997). Mexican American and Anglo attitudes toward immigration reform: A view from the border. Social Science Quarterly, 78(2), 324-337.

Blalock, H. M. (1967). Toward a theory of minority-group relations. New York, NY: John Wiley \& Sons.

Bogardus, E. S. (1925). Measuring social distance. Journal of Applied Sociology, 9, 299-308.

Bogardus, E. S. (1967). A forty year racial distance study. Los Angeles, CA: University of Southern California.
Brewer, M. B., \& Miller, N. (1984). Beyond the contact hypothesis: Theoretical perspectives on desegregation. In N. Miller \& M. B. Brewer (Eds.), Groups in contact: The psychology of desegregation (pp. 281-302). Amsterdam: Elsevier. Retrieved from http://linkinghub. elsevier.com/retrieve/pii/B978012497780850019X

Bridges, S., \& Mateut, S. (2014). Should they stay or should they go? Attitudes towards immigration in Europe. Scottish Journal of Political Economy, 61(4), 397-429. https://doi.org/10.1111/sjpe.12051

Buckler, K., Swatt, M. L., \& Salinas, P. (2009). Public views of illegal migration policy and control strategies: A test of the core hypotheses. Journal of Criminal Justice, 37(4), 317-327. https://doi.org/10.1016/ j.jcrimjus.2009.06.008

Campbell, D. T. (1967). Stereotypes and the perception of group differences. American Psychologist, 22(10), 817-829. https://doi.org/10.1037/h0025079

Constantinou, S. T., \& Harvey, M. E. (1985). Dimensional structure and intergenerational differences in ethnicity: The Greek Americans. Sociology \& Social Research, 69(2), 234-254.

Cook, S. W. (1978). Interpersonal and attitudinal outcomes in cooperating interracial groups. Journal of Research \& Development in Education, 12, 97-113.

de Graaf, P. M., Kalmijn, M., Kraaykamp, G., \& Monden, C. (2010). Design and content of the Netherlands Longitudinal Life course Study (NELLS). Nijmegen: Tilburg University and Radboud University.

Denton, N. A., \& Massey, D. S. (1988). Residential segregation of Blacks, Hispanics, and Asians by socioeconomic status and generation. Social Science Quarterly, 69(4), 797-815.

Diamond, J. (1998). African-American attitudes towards United States immigration policy. International Migration Review, 32(2), 451-470. https://doi.org/10. 2307/2547191

Dustmann, C., Frattini, T., \& Lanzara, G. (2012). Educational achievement of second-generation immigrants: An international comparison. Economic Policy, 27(69), 143-185. https://doi.org/10.1111/j. 1468-0327.2011.00275.x

European Social Survey. (2018). ESS cumulative data wizard. European Social Survey. Retrieved from https:// www.europeansocialsurvey.org/downloadwizard

Freeman, L. (2000). Minority housing segregation: A test of three perspectives. Journal of Urban Affairs, 22(1), 15-35. https://doi.org/10.1111/0735-2166.00037

Hainmueller, J., \& Hiscox, M. J. (2007). Educated preferences: Explaining attitudes toward immigration in Europe. International Organization, 61(2). https://doi. org/10.1017/S0020818307070142

Hammarstedt, M. (2009). Intergenerational mobility and the earnings position of first-, second-, and third-generation immigrants. Kyklos, 62(2), 275-292. https://doi.org/10.1111/j.1467-6435.2009.00436.x

Hayes, B. C., \& Dowds, L. (2006). Social contact, cultural marginality or economic self-interest? Attitudes to- 
wards immigrants in Northern Ireland. Journal of Ethnic and Migration Studies, 32(3), 455-476. https:// doi.org/10.1080/13691830600554890

Hill, P. B. (1984). Räumliche Nähe und soziale Distanz zu ethnischen Minderheiten [Spacial proximity and social distance towards ethnic minorities]. Zeitschrift Für Soziologie, 13(4), 363-370. https://doi.org/10. 1515/zfsoz-1984-0406

Hindriks, P., Verkuyten, M., \& Coenders, M. (2014). Interminority attitudes: The roles of ethnic and national identification, contact, and multiculturalism. Social Psychology Quarterly, 77(1), 54-74. https://doi.org/ 10.1177/0190272513511469

Hood, M. V., Morris, I. L., \& Shirkey, K. A. (1997). "iQuedate o vente!": Uncovering the determinants of Hispanic public opinion toward immigration. Political Research Quarterly, 50(3), 627-647. https://doi.org/10. 1177/106591299705000307

ISSP Research Group. (2015). ZA5950: International social survey programme: National identity III - ISSP 2013 [Data file version 2.0.0]. https://doi.org/10. $4232 / 1.12312$

Jensen, L., \& Chitose, Y. (1994). Today's second generation: Evidence from the 1990 U.S. census. International Migration Review, 28(4), 714-735. https://doi. org/10.2307/2547155

Jolly, S. K., \& DiGiusto, G. M. (2014). Xenophobia and immigrant contact: French public attitudes toward immigration. The Social Science Journal, 51(3), 464-473. https://doi.org/10.1016/j.soscij.2013.09.018

Just, A., \& Anderson, C. J. (2015). Dual allegiances? Immigrants' attitudes toward immigration. The Journal of Politics, 77(1), 188-201. https://doi.org/10.1086/ 678388

Lancee, B., \& Hartung, A. (2012). Turkish migrants and native Germans compared: The effects of interethnic and intra-ethnic friendships on the transition from unemployment to work. International Migration, 50(1), 39-54. https://doi.org/10.1111/j.14682435.2011.00736.x

Lubbers, M. J., Molina, J. L., \& McCarty, C. (2007). Personal networks and ethnic identifications: The case of migrants in Spain. International Sociology, 22(6), 721-741. https://doi.org/10.1177/ 0268580907082255

Maddux, C. D., Scheiber, L. M., \& Bass, J. E. (1982). Self-concept and social distance in gifted children. Gifted Child Quarterly, 26(2), 77-81. https://doi.org/ 10.1177/001698628202600207

Martinović, B. (2013). The inter-ethnic contacts of immigrants and natives in the Netherlands: A twosided perspective. Journal of Ethnic and Migration Studies, 39(1), 69-85. https://doi.org/10.1080/ 1369183X.2013.723249

Masuda, M., Hasegawa, R. S., \& Matsumoto, G. (1973). The ethnic identity questionnaire: A comparison of three Japanese age groups in Tachikawa, Japan, Honolulu, and Seattle. Journal of Cross-Cultural
Psychology, 4(2), 229-245. https://doi.org/10.1177/ 002202217300400207

Masuda, M., Matsumoto, G. H., \& Meredith, G. M. (1970). Ethnic identity in three generations of Japanese Americans. The Journal of Social Psychology, 81(2), 199-207. https://doi.org/10.1080/ 00224545.1970 .9922441

Mayda, A. M. (2006). Who is against immigration? A cross-country investigation of individual attitudes toward immigrants. Review of Economics and Statistics, 88(3), 510-530. https://doi.org/10.1162/rest. 88.3.510

Meuleman, B., Davidov, E., \& Billiet, J. (2009). Changing attitudes toward immigration in Europe, 2002-2007: A dynamic group conflict theory approach. Social Science Research, 38(2), 352-365. https://doi.org/10. 1016/j.ssresearch.2008.09.006

Musterd, S. (2005). Social and ethnic segregation in Europe: Levels, causes, and effects. Journal of Urban Affairs, 27(3), 331-348. https://doi.org/10.1111/j. 0735-2166.2005.00239.x

O'Rourke, K. H., \& Sinnott, R. (2006). The determinants of individual attitudes towards immigration. European Journal of Political Economy, 22(4), 838-861. https:// doi.org/10.1016/j.ejpoleco.2005.10.005

Park, R. E. (1924). The concept of social distance as applied to the study of racial attitudes and racial relations. Journal of Applied Sociology, 8, 339-344.

Pettigrew, T. F., \& Tropp, L. R. (2006). A meta-analytic test of intergroup contact theory. Journal of Personality and Social Psychology, 90(5), 751-783. https:// doi.org/10.1037/0022-3514.90.5.751

Polinard, J. L., Wrinkle, R. D., \& de la Garza, R. (1984). Attitudes of Mexican Americans toward irregular Mexican immigration. International Migration Review, 18(3), 782-799.

Quillian, L. (1995). Prejudice as a response to perceived group threat: Population composition and anti-immigrant and racial prejudice in Europe. American Sociological Review, 60(4), 586-611. https://doi. org/10.2307/2096296

Riek, B. M., Mania, E. W., \& Gaertner, S. L. (2006). Intergroup threat and outgroup attitudes: A metaanalytic review. Personality and Social Psychology Review, 10(4), 336-353. https://doi.org/10.1207/ s15327957pspr1004_4

Rouse, S. M., Wilkinson, B. C., \& Garand, J. C. (2010). Divided loyalties? Understanding variation in Latino attitudes toward immigration. Social Science Quarterly, 91(3), 856-882. https://doi.org/10.1111/ j.1540-6237.2010.00723.x

Semyonov, M., \& Glikman, A. (2009). Ethnic residential segregation, social contacts, and anti-minority attitudes in European societies. European Sociological Review, 25(6), 693-708. https://doi.org/10.1093/ esr/jcn075

Smith, T. W., Davern, M., Freese, J., \& Hout, M. (2018). General social surveys, 1972-2016. GSS Data Ex- 
plorer. Retrieved from https://gssdataexplorer.norc. org

Suro, R. (2005). Attitudes toward immigrants and immigration policy: Surveys among Latinos in the US and Mexico. Pew Research. Retrieved from https:// www.pewresearch.org/wp-content/uploads/sites/ 5/reports/52.pdf

Trevelyan, E., Gambino, C., Gryn, T., Larsen, L., Acosta, Y., Grieco, E., ... Walters, N. (2016). Characteristics of the U.S. population by generational status: 2013. Washington, DC: U.S. Census Bureau.

\section{About the Author}

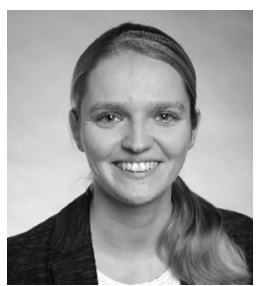

Charlotte Clara Becker is a PhD candidate at the Institute of Sociology and Social Psychology and a scholarship recipient of the Cologne Graduate School in Management, Economics and Social Sciences at the University of Cologne in Germany. In her dissertation she discusses attitudes towards immigration and immigrants. She is especially interested in the attitudes of currently under-researched social groups, such as persons with migration backgrounds and children. 


\section{Appendix}

Table A1. Details on the family origin.

\begin{tabular}{ll}
\hline Region (used in the analyses) & Categories in the GSS \\
\hline North American & French Canada, Other Canada, Mexico \\
\hline European & Austria, Czechoslovakia, Denmark, England \& Wales, Finland, France, \\
& $\begin{array}{l}\text { Germany, Greece, Hungary, Ireland, Italy, Netherlands, Norway, Poland, } \\
\text { Russia, Scotland, Spain, Switzerland, Portugal, Lithuania, Yugoslavia, } \\
\text { Rumania, Belgium, Other European }\end{array}$ \\
\hline African & Africa \\
\hline Asian & China, Japan, Philippines, India, Other Asian \\
\hline Spanish-speaking South and Middle American & Puerto Rico, West Indies, Other Spanish \\
\hline Other Origin & Arabic, Non-Spanish West Indies, Other \\
\hline
\end{tabular}

Table A2. Variables used in the analyses and descriptive statistics.

\begin{tabular}{|c|c|c|c|c|c|c|}
\hline Variable & Operationalisation & Min & Max & $\mathbf{M}$ & SD & Further Information; Percentages \\
\hline \multicolumn{7}{|l|}{ Dependent Variable } \\
\hline Attitude & $\begin{array}{l}5 \text { categories from } \\
\text { increase immigration } \\
\text { to America a lot to } \\
\text { reduce immigration a lot }\end{array}$ & 1 & 5 & 3.51 & 1.10 & $\begin{array}{l}\text { 1. Increased a lot: } 5 \% \\
\text { 2. Increased a little: } 10 \% \\
\text { 3. Remain the same: } 38 \% \\
\text { 4. Reduced a little: } 23 \% \\
\text { 5. Reduced a lot: } 24 \%\end{array}$ \\
\hline \multicolumn{7}{|l|}{ Migration History } \\
\hline $\begin{array}{l}\text { Migration } \\
\text { Background }\end{array}$ & $\begin{array}{l}=1 \text { if first-, second- or } \\
\text { third-generation }=1 ; \\
0 \text { otherwise }\end{array}$ & 0 & 1 & 0.40 & 0.49 & $\begin{array}{l}\text { In total: } 2,811 \\
\text { In percentage of the sample: } 38 \%\end{array}$ \\
\hline First-generation & $\begin{array}{l}=1 \text { if respondent and } \\
\text { both parents were born } \\
\text { outside the US; } 0 \text { otherwise }\end{array}$ & 0 & 1 & 0.11 & 0.32 & $\begin{array}{l}\text { In total: } 835 \\
\text { In percentage of the sample: } 11 \% \\
\text { In percentage of those with } \\
\text { migration background: } 30 \%\end{array}$ \\
\hline Second-generation & $\begin{array}{l}=1 \text { if respondent was } \\
\text { born in US and at least } \\
\text { one parent was born } \\
\text { outside the US; } 0 \text { otherwise }\end{array}$ & 0 & 1 & 0.09 & 0.29 & $\begin{array}{l}\text { In total: } 672 \\
\text { In percentage of the sample: } 9 \% \\
\text { In percentage of those with } \\
\text { migration background: } 24 \%\end{array}$ \\
\hline Third-generation & $\begin{array}{l}=1 \text { if respondent and } \\
\text { both parents were born } \\
\text { in the US and at least one } \\
\text { grandparent outside the US; } \\
0 \text { otherwise }\end{array}$ & 0 & 1 & 0.19 & 0.39 & $\begin{array}{l}\text { In total: } 1,304 \\
\text { In percentage of the sample: } 18 \% \\
\text { In percentage of those with } \\
\text { migration background: } 46 \%\end{array}$ \\
\hline
\end{tabular}

\section{Family Origin}

(further details see Appendix A1)

\begin{tabular}{|c|c|c|c|c|c|c|}
\hline North American & $\begin{array}{l}=1 \text { if migration background } \\
\text { and North American family } \\
\text { origin; } 0 \text { otherwise }\end{array}$ & 0 & 1 & 0.07 & 0.26 & $\begin{array}{l}\text { In total: } 497 \\
\text { In percentage of the sample: } 7 \% \\
\text { In percentage of those with } \\
\text { migration background: } 18 \%\end{array}$ \\
\hline European & $\begin{array}{l}=1 \text { if migration background } \\
\text { and European family } \\
\text { origin; } 0 \text { otherwise }\end{array}$ & 0 & 1 & 0.20 & 0.40 & $\begin{array}{l}\text { In total: } 1,347 \\
\text { In percentage of the sample: } 18 \% \\
\text { In percentage of those with } \\
\text { migration background: } 48 \%\end{array}$ \\
\hline
\end{tabular}


Table A2. (Cont.) Variables used in the analyses and descriptive statistics.

\begin{tabular}{|c|c|c|c|c|c|c|}
\hline Variable & Operationalisation & Min & Max & M & SD & Further Information; Percentages \\
\hline African & $\begin{array}{l}=1 \text { if migration background } \\
\text { and African family } \\
\text { origin; } 0 \text { otherwise }\end{array}$ & 0 & 1 & 0.01 & 0.10 & $\begin{array}{l}\text { In total: } 76 \\
\text { In percentage of the sample: } 1 \% \\
\text { In percentage of those with } \\
\text { migration background: } 3 \%\end{array}$ \\
\hline Asian & $\begin{array}{l}=1 \text { if migration background } \\
\text { and Asian family } \\
\text { origin; } 0 \text { otherwise }\end{array}$ & 0 & 1 & 0.03 & 0.18 & $\begin{array}{l}\text { In total: } 231 \\
\text { In percentage of the sample: } 3 \% \\
\text { In percentage of those with } \\
\text { migration background: } 8 \%\end{array}$ \\
\hline $\begin{array}{l}\text { Spanish-speaking } \\
\text { South and } \\
\text { Middle American }\end{array}$ & $\begin{array}{l}=1 \text { if migration background } \\
\text { and Spanish Speaking South- } \\
\text { or Middle-American family } \\
\text { origin; } 0 \text { otherwise }\end{array}$ & 0 & 1 & 0.03 & 0.18 & $\begin{array}{l}\text { In total: } 217 \\
\text { In percentage of the sample: } 3 \% \\
\text { In percentage of those with } \\
\text { migration background: } 8 \%\end{array}$ \\
\hline Other Origin & $\begin{array}{l}=1 \text { if migration background } \\
\text { and "other" family origin; } \\
0 \text { otherwise }\end{array}$ & 0 & 1 & 0.02 & 0.13 & $\begin{array}{l}\text { In total: } 111 \\
\text { In percentage of the sample: } 2 \% \\
\text { In percentage of those with } \\
\text { migration background: } 4 \%\end{array}$ \\
\hline \multicolumn{7}{|c|}{ Socio-economic Background } \\
\hline Age & In years & 18 & 88 & 47.94 & 17.32 & \\
\hline Male & $=1$ if male; 0 if female & 0 & 1 & 0.45 & 0.50 & $\begin{array}{l}\text { In total: } 3,323 \\
\text { In percentage of the sample: } 45 \%\end{array}$ \\
\hline Non-White & $\begin{array}{l}=1 \text { if identifies as a race } \\
\text { other than white; } 0 \text { otherwise }\end{array}$ & 0 & 1 & 0.25 & 0.43 & $\begin{array}{l}\text { In total: } 1,841 \\
\text { In percentage of the sample: } 25 \%\end{array}$ \\
\hline Education & $\begin{array}{l}=\text { highest year of school } \\
\text { completed }\end{array}$ & 0 & 20 & 13.60 & 2.98 & \\
\hline Unemployed & $\begin{array}{l}=1 \text { if temporarily not } \\
\text { working or unemployed; } \\
0 \text { otherwise }\end{array}$ & 0 & 1 & 0.07 & 0.25 & $\begin{array}{l}\text { In total: } 503 \\
\text { In percentage of the sample: } 7 \%\end{array}$ \\
\hline Inactive & $\begin{array}{l}=1 \text { if retired, housekeeping } \\
\text { or currently in education; } \\
0 \text { otherwise }\end{array}$ & 0 & 1 & 0.31 & 0.46 & $\begin{array}{l}\text { In total: } 2,283 \\
\text { In percentage of the sample: } 31 \%\end{array}$ \\
\hline $\begin{array}{l}\text { Other Labour } \\
\text { Force Status }\end{array}$ & $\begin{array}{l}=1 \text { if labour force status is } \\
\text { coded as other in GSS; } \\
0 \text { otherwise }\end{array}$ & 0 & 1 & 0.29 & 0.17 & $\begin{array}{l}\text { In total: } 212 \\
\text { In percentage of the sample: } 3 \%\end{array}$ \\
\hline \multicolumn{7}{|c|}{ Year of Data Collection } \\
\hline 2010 & $\begin{array}{l}=1 \text { if respondent participated } \\
\text { in 2010; } 0 \text { otherwise }\end{array}$ & 0 & 1 & 0.19 & 0.39 & $\begin{array}{l}\text { In total: } 1,381 \\
\text { In percentage of the sample: } 19 \%\end{array}$ \\
\hline 2012 & $\begin{array}{l}=1 \text { if respondent participated } \\
\text { in } 2012 ; 0 \text { otherwise }\end{array}$ & 0 & 1 & 0.17 & 0.38 & $\begin{array}{l}\text { In total: } 1,255 \\
\text { In percentage of the sample: } 17 \%\end{array}$ \\
\hline 2014 & $\begin{array}{l}=1 \text { if respondent participated } \\
\text { in } 2014 ; 0 \text { otherwise }\end{array}$ & 0 & 1 & 0.22 & 0.41 & $\begin{array}{l}\text { In total: } 1,611 \\
\text { In percentage of the sample: } 22 \%\end{array}$ \\
\hline 2016 & $\begin{array}{l}=1 \text { if respondent participated } \\
\text { in } 2016 ; 0 \text { otherwise }\end{array}$ & 0 & 1 & 0.25 & 0.43 & $\begin{array}{l}\text { In total: } 1,829 \\
\text { In percentage of the sample: } 25 \%\end{array}$ \\
\hline
\end{tabular}

Table A3. Compositions of the samples used in the four models.

\begin{tabular}{lcccc}
\hline Migration status & Model 1 & Model 2 & Model 3 & Model 4 \\
\hline No migration background & 4,155 & 4,155 & 4,155 & 4,155 \\
First-generation & 830 & 809 & 822 & 801 \\
Second-generation & 670 & 606 & 650 & 592 \\
Third-generation & 1,294 & 1,092 & 1,294 & 1,092 \\
\hline Total & 6,949 & 6,662 & 6,921 & 6,640 \\
\hline
\end{tabular}

